\title{
Biologic Entity Group Actual Indicator
}

National Cancer Institute

\section{Source}

National Cancer Institute. Biologic Entity Group Actual Indicator. NCI Thesaurus. Code C93739.

Specifies whether the biologic entity group is real (actual) vs. placeholder (kind of). 